\title{
Cardiac Fibroma
}

National Cancer Institute

\section{Source}

National Cancer Institute. Cardiac Fibroma. NCI Thesaurus. Code C6947.

A rare benign heart neoplasm usually occurring in young children. It is characterized by the presence of bland spindle cells and collagenous stroma formation. Clinical presentation may include cardiac arrhythmia, cyanosis, heart failure or sudden death. 